\title{
NILAI KEARIFAN LOKAL MASYARAKAT SEBAGAI PEMBELAJARAN IPS DALAM PENDIDIKAN KARAKTER
}

\author{
Rahimah \\ $\underline{2010128220022 @ \text { mhs.ulm.ac.id }}$
}

Prodi Pendidikan Ilmu Pengetahuan Sosial, FKIP, Universitas Lambung Mangkurat

\begin{abstract}
Abstrak
Pendidikan yang ada di Indonesia tentunya mengalami permasalahan. Dengan demikian perlunya pendidikan yang baik dalam pembentukan karakter dari peserta didik untuk menjadi masyarakat yang baik dalam kehidupannya. Perlu adanya penguatan karakter dalam menghadapi permasalahan yang ada. Memalui pendidikan karakter dalam pembelajaran IPS yang berbasis kearifan lokal ini untuk menanamkan kesadaran dan mampu beradaptasi dengan lingkungannya. Memiliki karakter yang baik maka tentunya akan menjadikan peserta didiknya menjadi warga yang baik sesuai dengan tujuan dari pendidikan IPS.
\end{abstract}

Kata kunci: Kearifan Lokal, Pendidikan Karakter, Pembelajaran IPS

PENDAHULUAN

Pada masa sekarang tidak hanya teknologi saja yang berkembang namun dari segi masyarakatnya juga berkembang. Perlu adanya penguatan karakter agar dalam menghadapi kemajuan yang ada dapat teratasi dengan baik tanpa terbawa arus yang lebih lagi dan mampu menyaring perubahan yang ada dengan baik. Dengan demikian perlu adanya penguatan karakter dalam pendidikan karakter ini sebagai dasar untuk penguatan bangsa. Selain itu kearifan lokal juga bermanfaat sebagai salah satu nilai luhur yang akan menjadi media bagi masyarakat dalam menghadap ke sebuah perkembangan Global yang semakin besar dan juga sebagai nilai kebijaksanaan atas perwujudan dari sebuah cita-cita bangsa Indonesia ini. IPS merupakan sebuah ilmu pengetahuan yang penting yang diminta tidak hanya menyajikan sebuah pengetahuan tentang sosialnya saja melainkan juga memimpin peserta didiknya agar menjadi masyarakat yang mempunyai tanggung jawab terhadap bangsa masyarakat dan negara. Pada pokok bahasan yang bisa jalan pada pembelajaran IPS tak hanya sebatas sebagai 
ruang lingkup materi akan pengetahuan namun juga sebagai nilai yang ada pada jati diri bangsa. Melalui pendidikan karakter pada pembelajaran IPS mampu dalam membentuk sebuah kayu pribadi anak yang baik dan manusia yang baik sehingga mampu mengantisipasi Atas kejadian suatu permasalahan baik itu dari segi menghadapi teknologi maupun krisis moral yang di mana hal tersebut berguna untuk membina diri seseorang. Pendidikan karakter di mampu menjadi sebuah solusi dalam menangani kasus masyarakat dalam ruang lingkup pendidikan untuk menjadikan peserta didik di masyarakat yang lebih baik lagi.

Kearifan lokal merupakan ciri dari suatu masyarakat yang berada di kawasan tersebut. Perlu adanya pemahaman dalam menjaga kearifan lokal yang ada di suatu masyarakat agar tidak hilang dari generasi ke generasi tas masuknya unsur budaya lain. Kearifan lokal ini tidak hanya berisi tentang suatu gagasan atau kegiatan tetapi juga mencakup sebuah interaksi antara manusia lain, manusia dan lingkungan dan juga manusia dengan sistem kepercayaan. Di era globalisasi ini perlu adanya pemeliharaan kearifan lokal yang baik agar tidak terkikis atas perubahan yang ada. Meskipun pada kenyataannya teknologi ini memiliki manfaat yang besar atas kenyamanan dari manusia itu sendiri namun kondisi ini dapat mengubah cara hidup dan berpikir serta pola dari sebuah hubungan manusia dengan lingkungannya. Dengan demikian perlu adanya sebuah kearifan lokal yang dijaga agar para generasi dapat menggunakan kearifan lokal sebagai penyaring dari berbagai aspek globalisasi pada elemen kehidupan masyarakat. Ilmu sosial merupakan sebuah pelajaran yang memadukan antara kearifan lokal dengan pembelajaran karena pada hakikatnya pembelajaran IPS ini memadukan dari nilai kearifan lokal dalam kegiatan belajarnya. Kenapa pada pembelajaran ilmu sosial ini bersumber dari kehidupan masyarakatnya dari pernyataan disebut perpaduan dari nilai kearifan lokal yang ada di masyarakat akan menjadi materi pembelajaran IPS yang mampu meningkatkan pengetahuan dan pemahaman mereka terhadap kearifan lokal masyarakat setempat. Pada dasarnya model pembelajaran dari IPS ini berorientasi kepada kearifan lokal atau budayanya dalam pengembangan keterampilan dan juga nilai dari karakter atas kearifan lokal yang ada bisanya pada nilai religius, pengetahuan dan lainnya yang berkaitan dengan nilai kearifan lokal. 


\section{METODE}

Pada penulisan ini menggunakan metode yang di mana materinya diperoleh dari jurnal dan buku lainnya yang relevan. Bahan yang sudah dikumpulkan lalu di pilah dan dipilih ke relevanannya dan kebenarannya. Setelah itu, dibuatlah serangkaian penulisan secara fakta dan dibentuklah dalam sebuah penulisan artikel.

\section{PEMBAHASAN}

\section{Pendidikan Karakter}

Pendidikan ialah sebuah jalan yang dikembangkan untuk memberikan pengetahuan kepada masyarakat dalam kearifan lokal yang mereka gunakan di dalam masyarakat yang digunakan sebagai pedoman hidup dari segala berbagai aspek. Pendidikan sebuah usaha atau aktivitas yang dilakukan seseorang dalam mewujudkan pengembangan potensi diri yang dilakukan secara sadar. Sedangkan karakter adalah sebuah kepribadian budi pekerti dan sifat pada diri seseorang yang dan karakter ini bisa dibangun dan dikembangkan melalui proses pendidikan karena karakter ini tidak instan terjadi dalam membentuk karakter seseorang. Jadi dapat disimpulkan bahwa pendidikan karakter itu bertujuan untuk membentuk sifat seseorang yang berakhlak mulia berjiwa Patriot dan memiliki jiwa keimanan serta rasa ketakwaan terhadap Tuhan Yang Maha Esa.

Nilai pendidikan karakter lebih menitikberatkan kepada sebuah pendidikan budi pekerti agar memiliki nilai kebaikan seperti yang disampaikan oleh Ki Hajar Dewantara bahwa pengajaran budi pekerti ini akan menuju ke arah peradaban dalam sifatnya yang lebih umum dalam perkembangan hidup si anak lahir maupun batin ya. Nilai karakter ini akan menjadi pedoman hidup bagi seseorang yang digunakan dalam mencapai sebuah ke bermanfaatan dan Kedamaian. Nilai keutamaan dari sebuah karakter ini dalam mencapai sebuah ke bermanfaatan kedamaian untuk hidupnya baik itu untuk dirinya, masyarakat maupun bagi negara.

\section{Kearifan Lokal Masyarakat}

Kearifan lokal itu sendiri yang berasal dari dua kata yaitu kearifan dan lokal. Ada yang memaknai kearifan lokal ini sebuah gagasan yang bijak dan menjadi pedoman dalam masyarakat sedangkan secara Antropologisnya bahwa dari sebuah pengetahuan dalam kelompok tertentu atau sebagai identitas dari budaya setempat titik sebagai wujud budaya tidak hanya berupa atas gagasan namun juga aktivitas yang mencerminkan dari 
sebuah nilai tersebut yang dibentuk oleh masyarakat itu sendiri Kearifan lokal ini berbeda pada setiap wilayahnya dan mempunyai ciri khas tersendiri bagi setiap wilayah tersebut. Kearifan lokal yang dilakukan oleh masyarakat mulai dari duduknya atau sebagai warisan budaya nenek moyang mereka tetap dilakukan hingga sekarang ini. Kearifan lokal ini merupakan tindakan yang sudah menjadi kebudayaan oleh masyarakat itu sendiri atas hasil dari timbal balik dari antar manusia maupun alam dan makhluk hidup lainnya.

Kearifan lokal itu bisa berupa sebuah gagasan atau aktivitas yang mencakup akan interaksi dari manusia itu sendiri dengan sesama manusianya ataupun dengan lingkungannya maupun manusia dan sistem kepercayaannya tidak hal tersebut berfungsi sebagai kendali dari berbagai aktivitas manusia yang melibatkan kehidupan dari suatu masyarakat. Di masa globalisasi sekarang ini menjadi wacana dan perhatian yang serius. Karena kemajuan ilmu pengetahuan dan teknologi merupakan akibat dari globalisasi yang cenderung menghilangkan nilai-nilai sosial dan moral bagi masyarakat yang bersumber dari adanya pengembangan kearifan lokal (Abbas, 2018). Dengan demikian kearifan lokal di masyarakat harus dijaga titik agar para generasi muda dapat menggunakan kearifan lokal tersebut sebagai masukan atau penyaring di berbagai aspek khususnya di globalisasi yang semakin pesat di masyarakat. setiap kearifan lokal mengandung nilai dari aspek budaya sosial dan juga kepercayaan yang dimiliki oleh masyarakat setempat dalam hidupnya. Kearifan lokal itu sendiri merupakan sebuah hasil dari pemikiran manusia yang mengandung nilai akan kebijaksanaan dan kearifan pada masyarakat tersebut nilai yang terkandung pada kearifan lokal tersebut sudah menjadi tumbuhan menurun Sehingga menjadi sebuah karakter dari masyarakat setempat yang tentunya memiliki perbedaan dengan daerah masyarakat lainnya.

\section{Pentingnya Sebuah Pendidikan yang Berbasis Kearifan Lokal}

Potensi dari kearifan lokal itu sendiri dapat menjadi perpaduan dalam pembelajaran. Nilai dari kearifan lokal ini tidak hanya untuk sumber belajar namun juga sebagai pemberian pemahaman terhadap peserta didik sebagai pembentukan sebuah karakter peserta didiknya. Pemberian pembelajaran yang berbasis kearifan lokal ini diberikan sejak dini agar peserta didik dapat menggali dan penanaman budaya nilai luhur bangsa Indonesia ini. Manusia tidak hanya bekerja sama dengan sesama manusia, 
namun juga akan melakukan interaksi dengan lingkungan sekitarnya yaitu kebudayaan dan kearifan lokal masyarakatnya.

\section{Pendidikan Karakter dari Pembelajaran IPS Berbasis Kearifan Lokal Masyarakat}

Pembelajaran IPS ini merupakan pembelajaran yang sangat erat kaitannya dengan kehidupan kebudayaan dan kearifan lokal dari masyarakat yang ada. Tujuan dari pendidikan IPS itu sendiri agar menjadikan warganya menjadi masyarakat yang baik dalam kehidupan di masyarakat, bangsa dan juga negara. Selain itu juga, pembelajaran dari IPS ini bermanfaat untuk bisa menanamkan sikap yang baik di lingkungan sekitar masyarakat dalam kehidupan berbudaya dan memiliki kearifan lokal tersendiri di masyarakat seseorang tersebut berdiam. Seseorang tidak akan bisa terlepas dari kebudayaan yang ada di masyarakat dan tentunya hal tersebut untuk disadari. Tujuan dari pembelajaran IPS tersebut diterapkan di dalam lingkungan sekolah agar mampu mengenali suatu konsep yang berhubungan dengan kehidupan yang ada di masyarakat, memiliki kemampuan terampil dalam pola pikirnya dan kritis dalam hal yang berkenaan dengan lingkungan sosialnya, mempunyai rasa sadar yang tinggi terhadap antar manusia dan juga mampu bekerja sama dan berkomunikasi di antara masyarakatnya.

Mata pelajaran IPS itu sendiri dalam lingkung pendidikan sekolah dapat meningkatkan, menumbuhkan dan juga rasa sadar sebagai masyarakat yang mempunyai rasa tanggung jawab dalam menjalankan kehidupan. Dengan demikian, melalui pembelajaran IPS ini dapat menumbuhkan karakter seseorang pada kehidupan sosial dan juga mampu menerapkan kearifan lokal dengan baik. Menurut Atmodjo (1986) beliau mengatakan bahwa kearifan lokal ini kemampuan dalam menyaring atas kebudayaan asing yang masuk secara bijaksana. Kemampuan di sini sangat cocok diterapkan dan bagus dalam pembelajaran IPS itu sendiri agar para peserta didik mampu menyaring atas kebudayaan yang masuk. Menurut Supsilonami (2013) suatu kearifan lokal memiliki tiga jenisnya, yaitu:

a. System dari suatu nilai

Nilai yang ada pada masyarakat tentunya mengatur tentang sebuah etika baik itu etika yang buruk, baik, benar maupun yang salah. Nilai yang biasanya di terapkan dalam pembelajaran upaya pembentukan sebuah karakter anak adalah: 1) nilai keagamaan, di Indonesia sendiri masyarakatnya sangat menjunjung tinggi nilai keagamaan karena nilai pendidikan budaya dan karakter harus 
menjunjung sebuah nilai agama dalam lingkungan masyarakatnya. 2) nilai budaya, nilai budaya juga memiliki peran penting sebagai sumber pendidikan dan karakter karena nilai budaya ini akan menjadi pola dasar antar komunikasi dalam masyarakat. 3) nilai Pancasila, nilai dari Pancasila mengandung sebuah nilai politik, kemasyarakatan dan lainnya yang bertujuan dalam pembentukan warga negara yang baik.

b. Tata pengelolaan

Pada setiap daerahnya memiliki sistem dalam masyarakat yang berbeda dalam struktur sosialnya yang berhubungan dengan kelompok yang ada.

c. Tata cara

Dalam sebuah kebudayaan maupun kearifan lokal tentunya ada langkah atau tata cara dalam upaya menjalankan sebuah kebudayaan tersebut. Yang baik dan

Pendidikan karakter melalui pembelajaran IPS berbasis kearifan lokal ini kan membawa pada perubahan kesadaran untuk bisa lebih baik lagi. Nilai dari pembelajaran IPS ini sesuai sekali untuk membentuk karakter seseorang yang terkandung dalam pendidikan karakter serta kearifan lokal yang dimilikinya. Dengan karakter yang dimiliki maka akan mampu dalam menjaga kearifan lokal yang ada dan menyaring perubahan budaya asing yang masuk. Keterkaitan antara pembelajaran IPS ini dengan kearifan lokal adalah sebagai penyalur pengetahuan bagi penerus untuk mempertahankan kearifan lokal yang ada. Dengan memanfaatkan kearifan lokal pada pembelajaran IPS ini akan membentuk sebuah budaya yang kaya akan nilai sosialnya (Abbas, 2015; Widyanti, 2015). Penguatan karakter yang di dapat dari nilai kearifan lokal ini maka akan membuat peserta didik menjadi warga masyarakat yang baik di tengah kehidupan ini dan memiliki karakter berpikir kritis dalam menghadapi persoalan yang ada. Karena dalam Pendidikan IPS sendiri bertujuan agar menjadikan peserta didik yang baik dalam kehidupan. Dengan demikian pendidikan karakter dalam pendidikan IPS yang berbasis kearifan lokal ini akan membawa kemajuan.

\section{SIMPULAN}

Pendidikan karakter itu bertujuan untuk membentuk sifat seseorang yang berakhlak mulia berjiwa Patriot dan memiliki jiwa keimanan serta ketakwaan terhadap Tuhan Yang Maha Esa. Nilai keutamaan dari sebuah karakter ini dalam mencapai sebuah ke bermanfaatan kedamaian untuk hidupnya baik itu untuk dirinya, masyarakat 
maupun bagi negara. Kearifan lokal ini merupakan tindakan yang sudah menjadi kebudayaan oleh masyarakat itu sendiri atas hasil dari timbal balik dari antar manusia maupun alam dan makhluk hidup lainnya. Kearifan lokal itu bisa berupa sebuah gagasan atau aktivitas yang mencakup akan interaksi dari manusia itu sendiri dengan sesama manusianya ataupun dengan lingkungannya maupun manusia dan sistem kepercayaannya tidak hal tersebut berfungsi sebagai kendali dari berbagai aktivitas manusia yang melibatkan kehidupan dari suatu masyarakat. Nilai dari kearifan lokal ini tidak hanya untuk sumber belajar namun juga sebagai pemberian pemahaman terhadap peserta didik sebagai pembentukan sebuah karakter peserta didiknya. Pembelajaran IPS ini merupakan pembelajaran yang sangat erat kaitannya dengan kehidupan kebudayaan dan kearifan lokal dari masyarakat yang ada. Tujuan dari pendidikan IPS itu sendiri agar menjadikan warganya menjadi masyarakat yang baik dalam kehidupan di masyarakat, bangsa dan juga negara. Selain itu juga, pembelajaran dari IPS ini bermanfaat untuk bisa menanamkan sikap yang baik di lingkungan sekitar masyarakat dalam kehidupan berbudaya dan memiliki kearifan lokal tersendiri di masyarakat seseorang tersebut berdiam. Penguatan karakter yang di dapat dari nilai kearifan lokal ini maka akan membuat peserta didik menjadi warga masyarakat yang baik di tengah kehidupan ini dan memiliki karakter berpikir kritis dalam menghadapi persoalan yang ada. Karena dalam Pendidikan IPS sendiri bertujuan agar menjadikan peserta didik yang baik dalam kehidupan. Dengan demikian pendidikan karakter dalam pendidikan IPS yang berbasis kearifan lokal ini akan membawa kemajuan.

\section{REFERENSI}

Abbas, E. W. (2015). Pendidikan IPS Berbasis Kearifan Lokal. WAHANA JAYA ABADI.

Abbas, E. W. (2019). Membangun Karakter Bangsa Melalui Pendidikan: Prosiding Seminar Internasional Pendidikan Karakter.

Abbas, E. W., Handy, M. R., \& Shaleh, R. M. (2020). Ecotourism of Martapura River Banjarmasin as a Learning Resources on Social Studies. The Innovation of Social Studies Journal, 1(2), 111-119. 
Amirin, T. M. (2012). Implementasi pendekatan pendidikan multikultural konstektual berbasis kearifan lokal di Indonesia. Jurnal pembangunan pendidikan: Fondasi dan Aplikasi, 1(1).

Efendi, M., Sahrul, M., \& Salma, S. (2020). Nilai Kearifan Lokal Tradisi Manugal Masyarakat Dayak Meratus Kalimantan Selatan Pada Materi Geografi Bidang Lingkungan Hidup (Kajian Etnografi). PADARINGAN (Jurnal Pendidikan Sosiologi Antropologi), 2(2), 260-270.

Handy, M. R., Mutiani, M., Putra, M. A., \& Jumriani, J. (2020). The Religious Values in Tradition of Batahlil in Banjar Pahuluan Community. The Kalimantan Social Studies Journal, 2(1), 39-47.

Indriyani, I. E., Syaharuddin, S., \& Jumriani, J. (2021). Social Interaction Contents on Social Studies Learning to Improve Social Skills. The Innovation of Social Studies Journal, 2(2), 93-102.

Jumriani, J. (2018). KEGIATAN PRODUKSI DAN DISTRIBUSI DI KAMPUNG SASIRANGAN SEBAGAI SUMBER BELAJAR IPS. Jurnal Sucius, 7(1).

Jumriani, J., Mutiani, M., Putra, M. A., Syaharuddin, S., \& Abbas, E. W. (2021). The Urgency of Local Wisdom Content in Social Studies Learning: Literature Review. The Innovation of Social Studies Journal, 2(2), 103-109.

Purwanti, D. (2017). PENDIDIKAN KARAKTER PEDULI LINGKUNGAN DAN IMPLEMENTASINYA. DWIJA CENDEKIA: Jurnal Riset Pendagogik, 1(2).

Rahayu, R., Abbas, E. W., \& Jumriani, J. (2021). Social Studies Lesson Planning for Children with Intellectual Disabilities in the Pembina State Special School of Kalimantan Province. The Kalimantan Social Studies Journal, 2(2), 160-169. 